\title{
The Punky Wood Ambrosia Beetle and Fungus in Florida that Cause Wood Rot: Ambrosiodmus minor and Flavodon subulatus ${ }^{1}$
}

\author{
Demian F. Gomez and Jiri Hulcr²
}

\section{Summary}

Ambrosiodmus minor is an invasive ambrosia beetle in the southeastern United States, including Florida. It is considered of low importance because evident economic or ecological impacts have not been observed. However, it is associated with a unique ambrosia fungus, Flavodon subulatus, which causes rapid wood rot. Wood decay caused by this association between Ambrosiodmus and Flavodon is increasing in dead trees across the introduced range, especially in Florida. Here we provide guidance in identification of the pest, the symptoms of an infestation, and explanation of the insect's biology. In addition, we provide an updated overview of contemporary management and monitoring of the species.

\section{Introduction}

Ambrosia beetles are wood-boring insects that carry symbiotic fungi to be cultivated in galleries inside the wood. These beetles are common invasive insects because they can be transported in wood packaging material and untreated wood. A unique combination of small size, wood-boring habit, and inbreeding has made these beetles a highly successful group of invaders (Jordal et al. 2001). Several species are considered true pests that attack living trees, but most have been considered inconsequential.
However, this is perhaps because of the lack of studies on these introduced species. Their effects on wood decomposition and other ecosystem processes are yet to be seen.

In the last decade, one of the many new introductions in North America was the punky wood ambrosia beetle Ambrosiodmus minor (Stebbing 1909). This beetle was recorded for the first time in Florida during 2011 (Rabaglia and Okins 2011). Just as with other species within this genus, $A$. minor was considered of low importance because economic or ecological impacts were not immediately observed. However, the beetle is associated with a unique ambrosia fungus that decays wood. The fungus belongs to the group that includes mushrooms and bracket fungi and many wood-decay fungi. Ambrosiodmus minor and Flavodon subulatus, the decay fungus, are becoming common in dead trees across their introduced range (Figure 1) (You et al. 2015).

\section{Distribution}

Ambrosiodmus minor is native to southeastern Asia (Bangladesh, Bhutan, Burma, China, India, Thailand, Vietnam) (Wood and Bright 1992; Lin et al. 2019). It has been introduced in the United States and has been recorded thus far from Alabama, Florida, Georgia, and Mississippi.

1. This document is FOR365, one of a series of the School of Forest Resources and Conservation, UF/IFAS Extension. Original publication date December 2020. Visit the EDIS website at https://edis.ifas.ufl.edu for the currently supported version of this publication.

2. Demian F. Gomez, research assistant, School of Forest Resources and Conservation; and Jiri Hulcr, associate professor, School of Forest Resources and Conservation and the Entomology and Nematology Department; UF/IFAS Extension, Gainesville, FL 32611.

The Institute of Food and Agricultural Sciences (IFAS) is an Equal Opportunity Institution authorized to provide research, educational information and other services

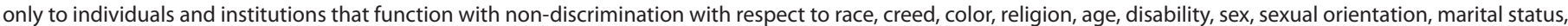

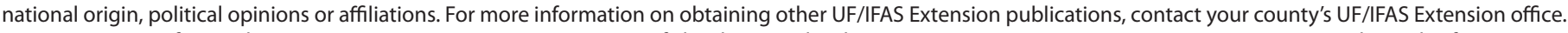
U.S. Department of Agriculture, UF/IFAS Extension Service, University of Florida, IFAS, Florida A \& M University Cooperative Extension Program, and Boards of County Commissioners Cooperating. Nick T. Place, dean for UF/IFAS Extension. 
This species has rapidly increased its frequency throughout the state of Florida since 2014 (Hulcr et al. 2018).
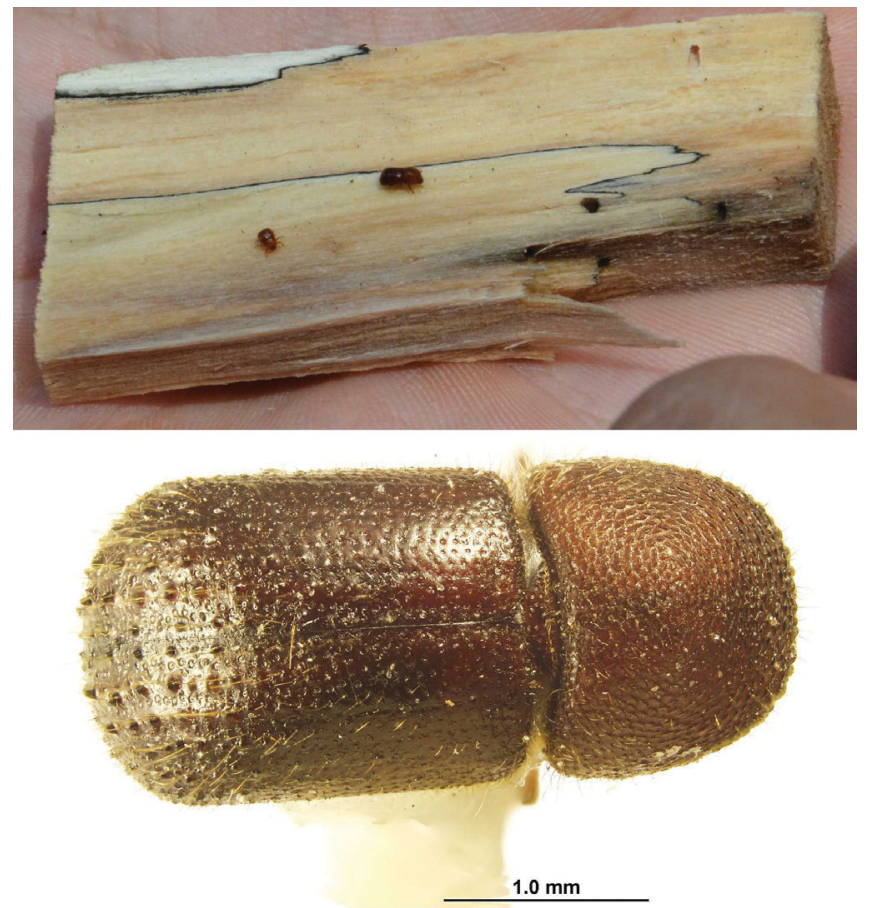

Figure 1. Top: male (left, small size) and female (right, larger size) of Ambrosiodmus minor and their galleries on a piece of decayed wood in Florida. Bottom: Female of Ambrosiodmus minor in dorsal view. Credits: Jiri Hulcr and Demian F. Gomez, University of Florida

\section{Identification}

Identification of ambrosia beetles such as A. minor can be difficult for non-specialists, and we therefore recommend consulting with a trained entomologist, such as the UF/ IFAS Forest Entomology Lab or Extension offices for final identification. In the eastern United States, there are two other non-native Ambrosiodmus species (A. lewisi and A. rubricollis), five native species (A. devexulus, A. lecontei, A. obliquus, A. opimus, and A. tachygraphus), and many similar looking ambrosia beetles and bark beetles.

Beetles in the genus Ambrosiodmus can be identified by little flat teeth that completely cover the top part of the thorax. Ambrosiodmus minor can be distinguished from other Ambrosiodmus species by its dark brown body, its large body size, and its small bumps of similar size in the rear end of the beetle (elytral declivity). This species is bigger and bulkier than most Ambrosiodmus, and it is now by far the most common Ambrosiodmus in the southeastern United States, where other species also live but are unlikely to be encountered. For detailed information on identification of this species, taxonomic keys for all species are provided in Gomez et al. (2018).
Wood colonized by A. minor shows distinct areas of white rot surrounding the gallery entry holes (Figure 2). Galleries are typically clustered, which is unusual among ambrosia beetles. The entrance hole has a perfectly circular shape and $1.5 \mathrm{~mm}$ diameter. Most native wood borers with holes of this size have entrances less circular, and their holes are less aggregated.

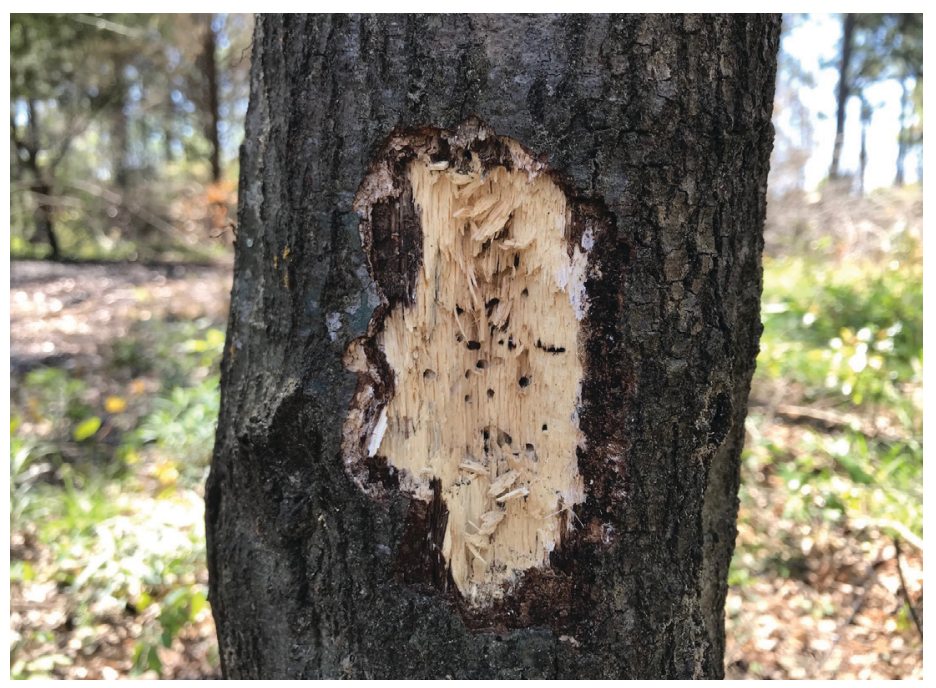

Figure 2. A typical cluster of galleries of Ambrosiodmus minor on a firestressed laurel oak in Florida, exposed by woodpeckers. Credits: Jiri Hulcr, University of Florida

\section{Biology and Ecology}

The majority of known associations between ambrosia beetles and ambrosia fungi involve Ascomycota fungi (the largest phylum of fungi), which do not decay wood. Instead these fungi depend on fresh tissues because they extract simple nutrients from freshly dead tree tissue. On the other hand, Flavodon subulatus is a genuine wood-rot fungus. Flavodon subulatus produces white rot, where both lignin and cellulose are broken down, leaving behind degraded wood that is white and soft (Figure 3). Accordingly, the Ambrosiodmus-Flavodon colonization starts the wood-decay process. The beetle-associated fungus Flavodon subulatus degrades cellulose and lignin rapidly, decomposing the wood faster than many native decay fungi (Kasson et al. 2016).

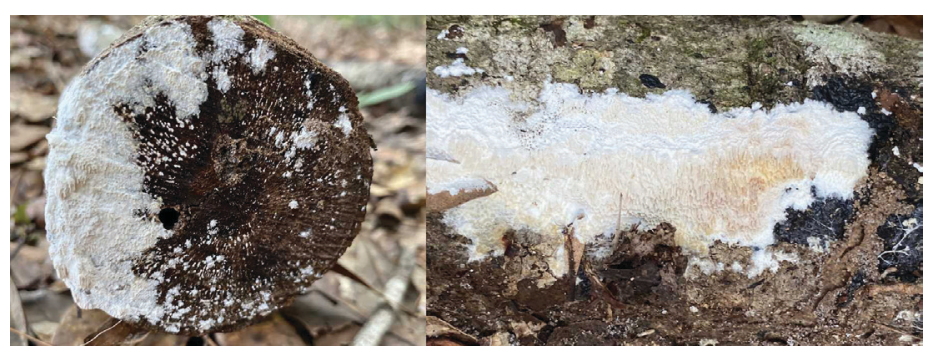

Figure 3. Fruiting bodies of Flavodon subulatus on a Florida oak log. The fruiting bodies are a white crust with a surface composed of irregular pores. The fruiting bodies can sometimes be observed on logs previously colonized by Ambrosiodmus minor. Credits: Demian Gomez, University of Florida 
The association between $A$. minor and a wood-decay fungus is not unique within the ambrosia beetles. All species within the genus Ambrosiodmus, as well as species within the closely related genus Ambrosiophilus, show this association with wood-decaying Flavodon species in both native and introduced regions (Li et al. 2017).

\section{Hosts}

People are most likely to encounter A. minor galleries in broken limbs of laurel oaks (Quercus laurifolia) and water oaks (Q. nigra). However, Ambrosiodmus minor is highly polyphagous and has been recorded as attacking plants in many different families, including Anacardiaceae (cashews), Combretaceae (tropical almonds), Dipterocarpaceae, Euphorbiaceae (spurges), Fabaceae (legumes), Lamiaceae (mints), Lauraceae (avocado), and Malvaceae (mallows), Salicaceae (willows), and Pinaceae (pines) (Wood and Bright 1992; Lin et al. 2019; Atkinson 2020). In Florida, this species has also been recorded attacking Altingiaceae, Fagaceae and Platanaceae.

\section{Impact}

Despite being considered an inconsequential introduction, the rapid spread of Ambrosiodmus minor in Florida may have an unintended consequence: the wood-rot fungus Flavodon subulatus may have an impact on wood degradation.

Ambrosiodmus minor could have two main types of effect. First, there could be an impact in urban settings because the Ambrosiodmus-Flavodon duo causes rapid decay in common urban trees. Because of their clustered attacks, limb breakage in urban trees is common, potentially causing property damage after windstorms. Second, the fact that this species is associated with a rapid wood-degrader could cause an ecological impact in forest ecosystems. The fungus Flavodon subulatus decomposes the wood faster than other common wood-decayers that occur naturally (Kasson et al. 2016).

Because the southeastern United States is extensively forested, wood decay is the dominant process of biomass recycling. This species is currently the only Ambrosiodmus that is now commonly found in conifers (specifically Pinus) in the region, but whether it will be noticeable in pine lumber is not yet clear. Because it occurs in temperate Asia, this species has the potential to expand its range across eastern North America, where the climate is similar (Lin et al. 2019).
Ambrosiodmus minor is the third Asian Ambrosiodmus species to have arrived in the United States, but its abundance has already far surpassed the earlier two species in less than a decade (Figure 4). All three species are widespread across Florida, but in terms of abundance only $A$. minor is growing exponentially. If the trend continues, it will probably become much more common across the region.

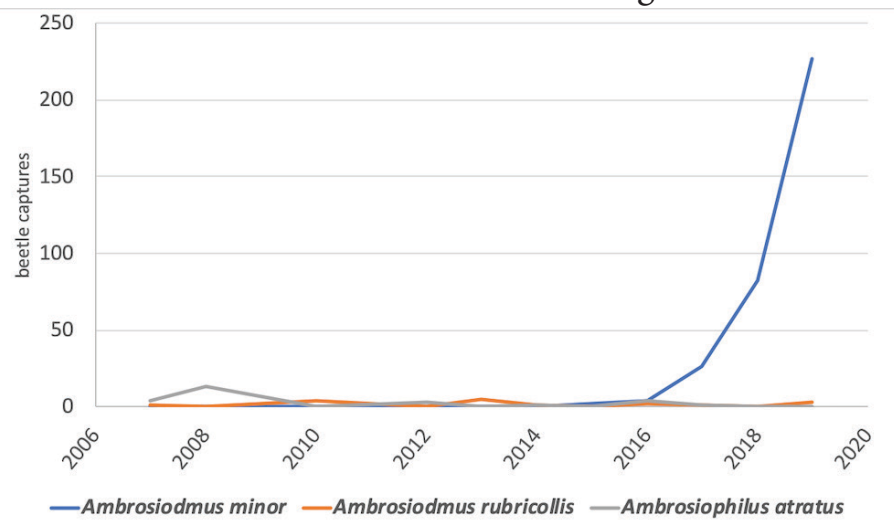

Figure 4. Data represents total captures of Ambrosiodmus minor, A. rubricollis, and Ambrosiophilus atratus retrieved from the Early Detection and Rapid Response Surveillance Program for Non-Native Bark and Ambrosia Beetles (USDA Forest Service). Three multi-funnel Lindgren traps with different lures are deployed on each of the twelve sites selected yearly across Florida. Specimens are collected every 2 weeks over a 12-week period every year. Sites are selected in collaboration with the Cooperative Agricultural Pest Survey (CAPS). Credits: Data provided by Dr. Sarah M. Smith-Cognato

\section{Survey and Monitoring}

This species is frequently collected in the USDA Forest Service Program of Surveillance for Non-Native Bark and Ambrosia Beetles, Early Detection and Rapid Response (EDRR), using Lindgren traps lured with alpha-pinene and ethanol. However, it seems to be only weakly attracted to ethanol compared to some other ambrosia beetles. It is sometimes attracted to lights, and can be even found indoors, especially in the spring.

\section{Prevention and Control}

Damage caused by Ambrosiodmus minor and Flavodon subulatus is still marginal, and very difficult to predict; therefore no specific management is recommended at this time. Greater impacts may become more evident as this species increases its range and abundance. No research on the management of $A$. minor exists, but some possible control strategies can be inferred from closely related species. Preventative strategies for homeowners include:

- Keep trees as healthy as possible though proper silviculture. Tree species with sound wood, such as live oak (Quercus virginiana), are recommended over 
fast-growing, easily rotting species such as laurel oak ( $Q$. laurifolia) and water oak (Q. nigra).

- Survey for oak trees showing branch dieback and signs of clustered beetle attack. Infested branches may be removed to prevent limb breakage and property damage. Pruning dead and diseased branches is recommended over spaces where people and structures occur. Pruning is not necessary in natural areas, and it is not recommended because dead wood serves important ecological functions in our landscapes.

\section{Acknowledgements}

We thank Sarah M. Smith-Cognato and the Early Detection and Rapid Response program from the USDA Forest Service for the surveillance data provided.

\section{References}

Atkinson, T. H. 2020. Bark and Ambrosia Beetles. www. barkbeetles.info.

Gomez, D. F., R. J. Rabaglia, K. E. O. Fairbanks, and J. Hulcr. 2018. "North American Xyleborini North of Mexico: A Review and Key to Genera and Species (Coleoptera, Curculionidae, Scolytinae)." Zookeys. 768:19-68.

Hulcr, J., J. Skelton, A. J. Johnson, Y. Li, and M. A. Jusino. 2018. "Invasion of an Inconspicuous Ambrosia Beetle and Fungus May Alter Wood Decay in Southeastern North America." PeerJ Preprints 6:e27334v1 https://doi. org/10.7287/peerj.preprints.27334v1

Jordal, B. H., R. A. Beaver, and L. R. Kirkendall. 2001. "Breaking Taboos in the Tropics: Incest Promotes Colonization by Wood-Boring Beetles." Glob. Ecol. Biogeogr. 10:345-357.

Jusino, M. A., J. Skelton, C. C. Chen, J. Hulcr, and M. E. Smith. 2020. "Sexual Reproduction and Saprotrophic Dominance by the Ambrosial Fungus Flavodon subulatus (= Flavodon ambrosius)." Fungal Ecol. 47:1-9.

Jusino, M., J. Skelton, Y. Li, A. Johnson, J. Hulcr, and M. Smith. 2019. "Evidence of Multiple Evolutionary Origins of Beetle-Farmed Decay Fungi," in Mycol. Soc. Am. Meet. Minneapolis. p. 41

Kasson, M. T., K. L. Wickert, C. M. Stauder, A. M. Macias, M. C. Berger, D. R. Simmons, D. P. G. Short, D. B. DeVallance, and J. Hulcr. 2016. "Mutualism with Aggressive Wood-Degrading Flavodon ambrosius (Polyporales)
Facilitates Niche Expansion and Communal Social Structure in Ambrosiophilus Ambrosia Beetles." Fungal Ecol. 23:86-96.

Li, Y., C. C. Bateman, J. Skelton, M. A. Jusino, Z. J. Nolen, D. R. Simmons, and J. Hulcr. 2017. "Wood Decay Fungus Flavodon ambrosius (Basidiomycota: Polyporales) Is Widely Farmed by Two Genera of Ambrosia Beetles." Fungal Biol. 121:984-989.

Lin, W., Y. Li, A. J. Johnson, and L. Gao. 2019. "New Area Records and New Hosts of Ambrosiodmus minor (Stebbing) (Coleoptera: Curculionidae: Scolytinae) in Mainland China." Coleopt. Bull. 73:684.

Rabaglia, R. J., and K. E. Okins. 2011. "Entomology Section." Tri-ology. 50:6-9.

Simmons, D. R., Y. Li, C. C. Bateman, and J. Hulcr. 2016. "Flavodon ambrosius sp. nov., a Basidiomycetous Mycosymbiont of Ambrosiodmus Ambrosia Beetles." Mycotaxon. 131:277-285.

Wood, S. L., and D. E. Bright. 1992. "A Catalog of Scolytidae and Platypodidae (Coleoptera), Part 2: Taxonomic Index, Volumes A and B." J. Chem. Inf. Model. 13:1-1553.

You, L., D. R. Simmons, C. C. Bateman, D. P. G. Short, M. T. Kasson, R. J. Rabaglia, and J. Hulcr. 2015. "New FungusInsect Symbiosis: Culturing, Molecular, and Histological Methods Determine Saprophytic Polyporales Mutualists of Ambrosiodmus Ambrosia Beetles." PLoS One. 10:1-13. 